\title{
Preparation of silica monolith via sol-gel route
}

\author{
A GUPTA, K BISWAS, A BASU MALLICK*, S MUKHERJEE and \\ G C DAS \\ Department of Metallurgical Engineering, Jadavpur University, Calcutta 700032, India \\ *Department of Metallurgical Engineering, Bengal Engineering College, Howrah 711103. \\ India \\ MS received 25 January 1995; revised 3 June 1995
}

\begin{abstract}
The present investigation deals with the synthesis of monolithic $\mathrm{NiCl}_{2}$-silica gels obtained by hydrolysis and polycondensation of tetraethoxy silanes. This sol to gel formation can mainly be controlled by adjusting some variables e.g. acid content of the solution, ageing and leaching times. A minimum acid content was found necessary to prepare uncracked gel while ageing and leaching times were found to be not that sensitive for the formation of uncracked gels.
\end{abstract}

Keywords. Monolith: sol-gel.

\section{Introduction}

Sol-gel processing has presently become the most modern approach for inorganic hybrid material development because of its simplicity and effectiveness (Mackenzie 1988; Ganguli 1989). During the last few years, extensive research has been carried out to prepare glass-metal micro/nanocomposites without melting via the sol-gel-route by in situ reduction of metallic salts in the silica gel matrix (Das et al 1990; Basumallick et al 1993). In spite of this phenomenal development, the use of this new class of materials in commercial and technological exploitation as superparamagnetic materials, substrates of semiconduction technology, optical communication, photothermal conversion devices and others are few and an urge to prepare these composites in the monolithic forms has now bloomed into a valid commercial proposition in many cases. The drying of gel is severely handicapped by cracking problems. This is caused mainly by the stresses due to capillary force arising from solvent-gel interfacial tension during drying. It is reported in the literature (De et al 1990) that for monolith, the proportion of acid should substantially be controlled within catalytic amounts $(0.4$ $0.7 \mathrm{~mol}$ per mole of alkoxide) leading to interesting final products. Though the acid is a must in the initial stages, its removal by washing is an essential prerequisite for obtaining monolithicity. The water and TEOS content of the starting solution should be in the ratio of $10: 1$ on molar basis. After gelling, the higher the ageing time, the higher will be the polycondensation leading to more rigid structure which is likely to withstand more drying stress and hence it is expected that it will affect the formation of monolithic gel. So it is important to know, to what extent the parameters such as acid content, ageing and leaching times are significant for the formation of monolithic gel. In this paper we report the result on the relative importance of these above factors for controlling the monolithicity during drying of gel. 


\section{Experimental}

Virgin gel samples were prepared with the compositions as given in table 1.

A homogeneous solution of double distilled water and requisite amount of $8(\mathrm{~N}) \mathrm{HCl}$ is thoroughly made. This solution is then added dropwise into a beaker containing TEOS of Fluka made ( $>98 \%$ ) placed upon a magnetic stirrer with the reaction temperature controlled at $22^{\circ}-24^{\circ} \mathrm{C}$. The resulting solution is left for gelling at room temperature after transferring it to a glass cylinder of $2.5 \mathrm{~cm}$ diameter. Gelation of the sols prepared in this way occurs within one or two days. The time interval between gelling and addition of water for leaching out the acid is the ageing time. The ageing time was varied within range of $24 \mathrm{~h}$ to $72 \mathrm{~h}$. After ageing the gel sample is dipped in double distilled water of 30 c.c. This water is decanted after $24 \mathrm{~h}$ and its $\mathrm{pH}$ level noted. Again 30 c.c. of double distilled water is poured and the above process is repeated. The leaching time is varied over 4 to 8 days. After leaching one set of gel, samples are immersed in concentrated $\mathrm{NiCl}_{2}$ and glucose solution for a few days when diffusion of $\mathrm{NiCl}_{2}$ and glucose into the gels occurs. The excess solution decanted and the samples prepared as above are kept in ordinary atmosphere and temperature for a few days. Ultimately, the samples are dried at $60^{\circ} \mathrm{C}$ in an oven for 10 days ( $6 \mathrm{~h}$ each day).

After drying it was noted visually which sample had cracked and which had not.

\section{Results and discussion}

Tables 2-4 summarize the effect of $8(\mathrm{~N}) \mathrm{HCl}$ content, ageing time and leaching time on the monolithic behaviour of gel samples after drying. Tables 5-7 represent the

Table 1. Composition of gel.

\begin{tabular}{lccccc}
\hline Composition & $\begin{array}{c}\text { TEOS } \\
\text { (c.c.) }\end{array}$ & $\begin{array}{c}\text { Mol. ratio } \\
\text { TEOS: } \mathrm{H}_{2} \mathrm{O}\end{array}$ & $\begin{array}{c}\text { Double } \\
\text { distilled } \\
\text { water (c.c.) }\end{array}$ & $\begin{array}{c}8(\mathrm{~N}) \mathrm{HCl} \\
\text { (c.c.) }\end{array}$ & $\begin{array}{c}\text { Mol. ratio } \\
\text { TEOS:HCl }\end{array}$ \\
\hline 1 & 5 & $1: 17$ & $5 \cdot 5$ & 1.5 & $1: 0 \cdot 54$ \\
2 & 5 & $1: 17$ & $5 \cdot 0$ & $2 \cdot 0$ & $1: 0 \cdot 72$ \\
3 & 5 & $1: 17$ & $4 \cdot 5$ & $2 \cdot 5$ & $1: 0.90$ \\
\hline
\end{tabular}

Table 2. Effect of ageing and leaching time on the cracking behaviour of silica gel for 1.5 c.c. $8(\mathrm{~N}) \mathrm{HCl}$ content during drying.

\begin{tabular}{lllllc}
\hline $\begin{array}{l}\text { Ageing time } \\
\text { (h) } \downarrow\end{array}$ & $\begin{array}{c}\text { Leaching time } \\
\text { (days) } \rightarrow\end{array}$ & 4 & 6 & 8 & $\begin{array}{c}\text { Number of } \\
\text { samples } \\
\text { uncracked }\end{array}$ \\
\hline 24 & & $\begin{array}{l}\text { Uncracked } \\
\text { Cracked } \\
\text { Uncracked }\end{array}$ & $\begin{array}{l}\text { Uncracked } \\
\text { Cracked } \\
\text { Cracked }\end{array}$ & $\begin{array}{l}\text { Cracked } \\
\text { Uncracked } \\
\text { Cracked } \\
\text { slightly }\end{array}$ & 2 \\
72 & 2 & 1 & 2 & 2 \\
$\begin{array}{l}\text { Number of samples } \\
\text { uncracked }\end{array}$ & & & & & \\
\hline
\end{tabular}


Table 3. Effect of ageing and leaching time on the cracking behaviour of silica gel for $2 \cdot 2$ c.c. $8(\mathrm{~N}) \mathrm{HCl}$ content during drying.

\begin{tabular}{lccccc}
\hline $\begin{array}{c}\text { Ageing time } \\
\text { (h) } \quad \begin{array}{c}\text { Leaching time } \\
\text { (days) } \rightarrow\end{array}\end{array}$ & 4 & 6 & 8 & $\begin{array}{c}\text { Number of } \\
\text { samples } \\
\text { uncracked }\end{array}$ \\
\hline 24 & & Cracked & Uncracked & Cracked & 1 \\
48 & & Cracked & Uncracked & Uncracked & 2 \\
72 & Uncracked & Cracked & Uncracked & 2 \\
Number of samples & 1 & 2 & 2 & 5 \\
uncracked & & & & \\
\hline
\end{tabular}

Table 4. Effect of ageing and leaching time on the cracking behaviour of silica gel for 2.5 c.c. $8(\mathrm{~N}) \mathrm{HCl}$ content during drying.

\begin{tabular}{|c|c|c|c|c|c|}
\hline $\begin{array}{l}\text { Ageing time } \\
\text { (h) } \quad \downarrow\end{array}$ & $\begin{array}{l}\text { Leaching time } \\
\qquad \text { (days) } \rightarrow\end{array}$ & 4 & 6 & 8 & $\begin{array}{l}\text { Number of } \\
\text { samples } \\
\text { uncracked }\end{array}$ \\
\hline 24 & & Uncracked & Uncracked & $\begin{array}{l}\text { Cracked } \\
\text { slightly }\end{array}$ & 3 \\
\hline 48 & & Uncracked & Uncracked & Uncracked & 3 \\
\hline 72 & & Uncracked & Uncracked & $\begin{array}{l}\text { Cracked } \\
\text { slightly }\end{array}$ & 3 \\
\hline $\begin{array}{l}\text { Number of samples } \\
\text { uncracked }\end{array}$ & & 3 & 3 & 3 & 9 \\
\hline
\end{tabular}

Table 5. Measurement of $\mathrm{pH}$ on days of leaching for $\mathrm{HCl}$ content 1.5 c.c.

\begin{tabular}{|c|c|c|c|c|c|c|c|c|c|}
\hline Sample No. & $\begin{array}{l}\text { Leaching } \\
\text { days }\end{array}$ & 1 & 2 & 3 & 4 & 5 & 6 & 7 & 8 \\
\hline 1 & & $0 \cdot 67$ & $1 \cdot 16$ & 1.90 & $3-30$ & - & - & - & - \\
\hline 2 & & 0.59 & $1 \cdot 24$ & 1.87 & $2 \cdot 60$ & $\cdots$ & - & - & - \\
\hline 3 & & 0.41 & 1.07 & 1.75 & $2 \cdot 35$ & 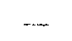 & - & - & - \\
\hline 4 & & $0 \cdot 75$ & 0.90 & $1 \cdot 22$ & 1.65 & $2 \cdot 04$ & $2 \cdot 60$ & - & - \\
\hline 5 & & $0 \cdot 37$ & 0.85 & 1.77 & $2 \cdot 20$ & $2 \cdot 88$ & 3.49 & - & - \\
\hline 6 & & 0.55 & $1 \cdot 21$ & 1.64 & $2 \cdot 25$ & 2.95 & 3.74 & - & - \\
\hline 7 & & $0 \cdot 33$ & 0.82 & 1.48 & $2 \cdot 17$ & $2 \cdot 83$ & $3 \cdot 53$ & $4 \cdot 53$ & 5.70 \\
\hline 8 & & $0 \cdot 38$ & 0.95 & $1 \cdot 64$ & $2 \cdot 30$ & 2.98 & $3 \cdot 76$ & 4.90 & $5 \cdot 60$ \\
\hline 9 & & $0-40$ & 0.96 & 1.57 & $2 \cdot 24$ & $2 \cdot 89$ & 3.67 & 5.07 & $6 \cdot 11$ \\
\hline
\end{tabular}

variation of $\mathrm{pH}$ of leached out solution as a function of leaching time for various gel samples prepared with different acid contents. Tables 2 and 3 recorded the samples prepared with 1.5 c.c. and 2 c.c. of $8(\mathrm{~N}) \mathrm{HCl}$ and show that slightly above $50 \%$ of gel samples remain in the monolith form while almost $100 \%$ of the gel samples made with 2.5 c.c. of $8(\mathrm{~N}) \mathrm{HCl}$ remain in the monolithic form (refer table 4). This suggests that in order to get gel monolith after drying, higher acid content is a must. However, the role of neither leaching time nor ageing time is decidingly significant (tables 2-4). It is reported that (De et al 1990) if the acid with which the gels are prepared is not leached out, the gel samples invariably cracked after drying. This implies that higher acid 
Table 6. Measurement of $\mathrm{pH}$ on days of leaching for $\mathrm{HCl}$ content 2.0 c.c. $8(\mathrm{~N})$.

\begin{tabular}{|c|c|c|c|c|c|c|c|c|c|}
\hline Sample No & $\begin{array}{l}\text { Leaching } \\
\text { days }\end{array}$ & 1 & 2 & 3 & 4 & 5 & 6 & 7 & 8 \\
\hline 1 & & 0.63 & $1 \cdot 12$ & $1 \cdot 82$ & $3 \cdot 32$ & - & - & - & - \\
\hline 2 & & 0.60 & $1 \cdot 25$ & 1.90 & $2 \cdot 66$ & - & - & - & - \\
\hline 3 & & 0.36 & 1.06 & 1.73 & $2 \cdot 35$ & - & - & - & - \\
\hline 4 & & 0.62 & 0.89 & $1 \cdot 24$ & $1 \cdot 71$ & $2 \cdot 18$ & $2 \cdot 75$ & - & - \\
\hline 5 & & $0 \cdot 31$ & 0.90 & 1.63 & $2 \cdot 12$ & $2 \cdot 79$ & $3 \cdot 35$ & - & - \\
\hline 6 & & 0.48 & 1.09 & $1 \cdot 51$ & $2 \cdot 12$ & $2 \cdot 78$ & 3.49 & - & - \\
\hline 7 & & 0.26 & 0.78 & $1.4 i$ & $2 \cdot 09$ & $2 \cdot 75$ & $3 \cdot 41$ & $4 \cdot 16$ & 5.65 \\
\hline 8 & & 0.28 & 0.83 & 1.50 & $2 \cdot 12$ & $2 \cdot 73$ & $3 \cdot 40$ & $4 \cdot 17$ & 4.80 \\
\hline 9 & & $0 \cdot 34$ & 0.86 & 1.45 & $2 \cdot 10$ & $2 \cdot 74$ & $3 \cdot 48$ & $4 \cdot 31$ & 6.07 \\
\hline
\end{tabular}

Table 7. Measurement of $\mathrm{pH}$ on days of leaching for $\mathrm{HCl}$ content $=2 \cdot 5$ c.c. $8(\mathrm{~N})$.

\begin{tabular}{|c|c|c|c|c|c|c|c|c|c|}
\hline Sample No & $\begin{array}{l}\text { Leaching } \\
\text { days }\end{array}$ & 1 & 2 & 3 & 4 & 5 & 6 & 7 & 8 \\
\hline 1 & & 0.60 & 0.97 & 1.65 & $2 \cdot 82$ & - & - & -- & $\ldots$ \\
\hline 2 & & 0.55 & 0.99 & 1.57 & $2 \cdot 28$ & - & - & - & - \\
\hline 3 & & $0 \cdot 30$ & 0.97 & 1.61 & $2 \cdot 19$ & - & - & - & - \\
\hline 4 & & 0.54 & 0.81 & $1 \cdot 10$ & 1.52 & 1.92 & $2 \cdot 48$ & - & - \\
\hline 5 & & 0.23 & 0.86 & $1 \cdot 50$ & 1.95 & 2.56 & $3 \cdot 16$ & $\ldots$ & - \\
\hline 6 & & 0.41 & 0.97 & $1 \cdot 37$ & 1.97 & $2 \cdot 57$ & $3 \cdot 22$ & - & - \\
\hline 7 & & 0.17 & 0.69 & $1 \cdot 29$ & 1.95 & $2 \cdot 57$ & $3 \cdot 17$ & 4.02 & $5 \cdot 22$ \\
\hline 8 & & 0.20 & 0.75 & $1 \cdot 40$ & 1.98 & $2 \cdot 57$ & $3 \cdot 23$ & $3 \cdot 84$ & $4 \cdot 60$ \\
\hline 9 & & $0 \cdot 26$ & 0.78 & $1 \cdot 30$ & 1.90 & $2 \cdot 57$ & $3 \cdot 29$ & $3 \cdot 81$ & 5.89 \\
\hline
\end{tabular}

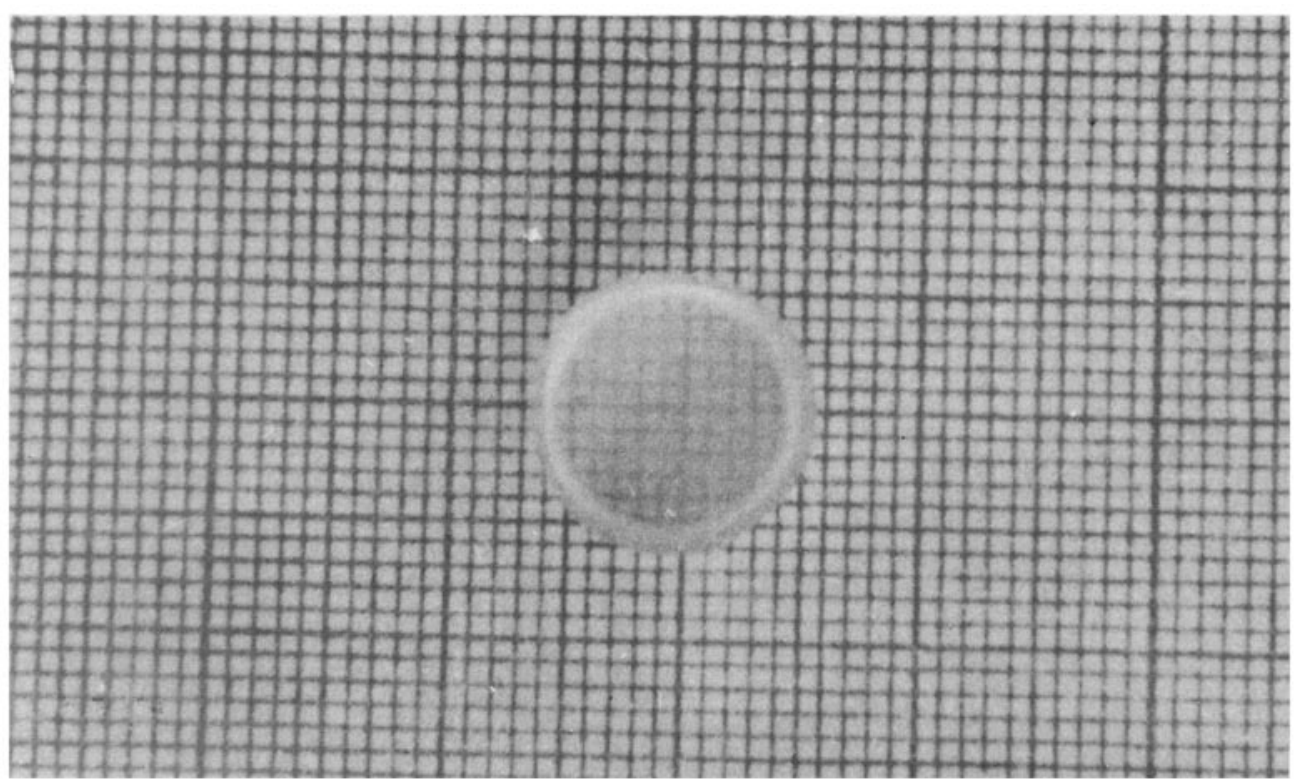

Figure 1. Optical photograph of virgin silica gel of sample no. 2 after drying, subjected to ageing for $48 \mathrm{~h}$ followed by 6 days of leaching. 


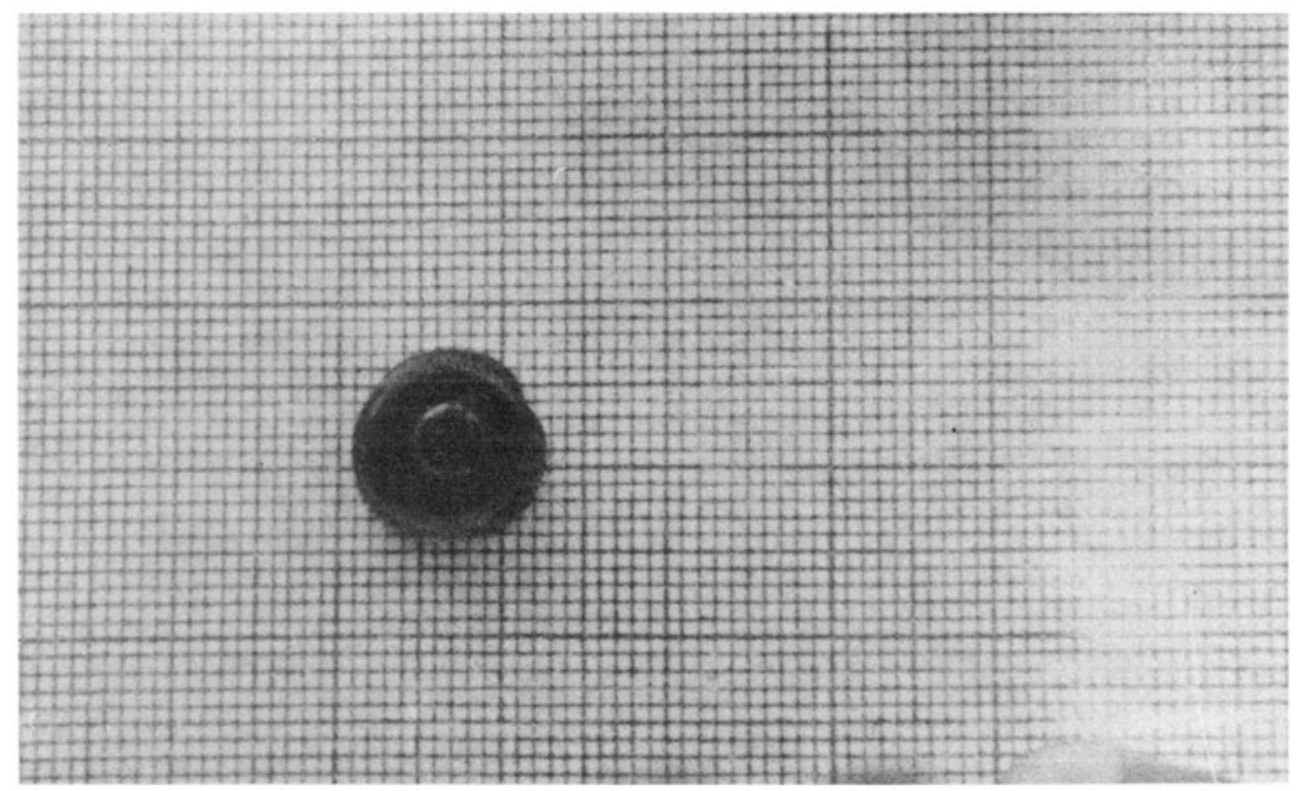

Figure 2. Optical photograph of silica gel of sample no. 3 containing $\mathrm{NiCl}_{2}$ and $\mathrm{C}_{6} \mathrm{H}_{12} \mathrm{O}_{6}$ after drying, subjected to ageing for $72 \mathrm{~h}$ followed by 6 days of leaching.

content after formation of the gel is detrimental during drying and causes fracture. This is the reason why one should leach out the acid in the gel before putting to drying. Tables 5-7 show that the $\mathrm{pH}$ of aqueous solution after 4 days of leaching is around 2 . Since the days of leaching beyond 4 days are not conclusively significant (tables 2-4), whatever acid left after 4 days of leaching is not significant in promoting fracture in the gel during drying. It is expected that with higher ageing time the polycondensation becomes more which should make the structure stronger to withstand drying stress. However, the gain in strength for ageing time up to $72 \mathrm{~h}$ is not always sufficient to avoid fracture.

Figures 1 and 2 show the typical optical photographs of monolithic virgin gel and gel sample containing $\mathrm{NiCl}_{2}$ and glucose after drying.

Therefore, it can be concluded that higher acid content [2.5c.c. of $8(\mathrm{~N}) \mathrm{HCl}]$ is a significant factor for the formation of monolithic gel. The ageing time and leaching time do not appear to be that significant.

\section{Acknowledgement}

Authors acknowledge the financial support from CSIR, New Delhi.

\section{References}

Basumallick A, Biswas K, Das G C and Mukherjee S 1993 Bull. Mater. Sci. 16317

Das G C, Mukherjee S and Basumallick A 1990 Bull. Mater. Sci. 13255

De G, Kundu D, Karmakar B and Ganguli D 1990 J. Non-Cryst. Solids 122219

Ganguli D 1989 Indian J. Phys. A63 253

Mackenzie J D 1988 J. Non-Cryst. Solids 139165 